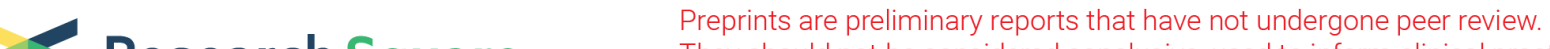 Research Square They should not be considered conclusive, used to inform clinical practice, or referenced by the media as validated information.
}

\section{Leaf Elemental Stoichiometry of Stellera Chamaejasme L. in Response to Environmental Factors in Degraded Grasslands Across Northern China}

\section{Lizhu Guo}

Beijing Academy of Agriculture and Forestry Sciences

\section{Li Liu}

Chinese Academy of Agricultural Sciences

\section{Huizhen Meng}

Northwest University

\section{Li Zhang}

Northwest University

\section{Valdson José Silva}

Federal Rural University of Pernambuco: Universidade Federal Rural de Pernambuco

\section{Kun Wang}

China Agricultural University

Wei He

Northwest University

Ding Huang ( $\sim$ huangding@263.net )

China Agricultural University

\section{Research Article}

Keywords: Stellera chamaejasme L., Biogeographic patterns, Stoichiometric homeostasis, Climatic variables, Inner Mongolia Plateau, Qinghai-Tibetan Plateau

Posted Date: September 9th, 2021

DOl: https://doi.org/10.21203/rs.3.rs-831766/v1

License: (c) (i) This work is licensed under a Creative Commons Attribution 4.0 International License. Read Full License 


\section{Abstract}

Plant leaf stoichiometry reflect its adaptations to environments. Leaf stoichiometry variations across different environments have been extensively studied among grassland plants, but little is known about intraspecific leaf stoichiometry, especially for widely distributed species, such as Stellera chamaejasme L. In order to evaluate the biogeographical drivers for leaf elemental stoichiometry in S. chamaejasme, leaf and soil samples were collected from 29 invaded sites in the two plateaus of distinct environments [the Inner Mongolian Plateau (IM) and Qinghai-Tibet Plateau (QT)] in Northern China. Leaf C, N, P, and K and their stoichiometric ratios, and soil physicochemical properties were determined. Results showed that mean leaf $C, N, P$, and $K$ concentrations were $498.60,19.95,2.15$, and $6.57 \mathrm{~g} \mathrm{~kg}^{-1}$, respectively; the $C / N$, $\mathrm{C} / \mathrm{P}$, and N/P ratios were $25.46,246.22$, and 9.84 , respectively. Only leaf $\mathrm{K}$ was significantly different between the two environments studied. Soil physicochemical properties of $S$. chamaejasme invaded area varied wildly, suggesting this wide ranging species tend to be insensitive to variation in soil nutrient availability. $\mathrm{C}$ and $\mathrm{N}$ content of $\mathrm{S}$. chamaejasme leaves were unaffected by any environmental factors. However, the stoichiometric homeostasis of $\mathrm{P}$ and $\mathrm{K}$ was observed. The correlation between leaf $\mathrm{P}$ and climate factors was significant only in $\mathrm{IM}$, while leaf $\mathrm{K}$ was significantly related to climate factors only in QT. Partial least squares path modeling suggested that soil exerted a significant effect on LP and climate affected leaf $\mathrm{P}$ and $\mathrm{K}$ both directly and indirectly in QT, while LP appeared to be limited mainly by climatic factors via direct ways and LK was not affected significantly by any environmental factors in IM. This study evaluated the $S$. chamaejasme leaf elemental stoichiometry and their relationships with environmental variables, which can help understand the plant biogeographic patterns and adaption strategy in degraded grasslands in China.

\section{Introduction}

Ecological stoichiometry is the study of the balance of energy and multiple chemical elements in ecological interactions, which plays an important role in analyzing the composition, structure, and function of a concerned community and ecological system (Elser et al. 2000; Sterner and Elser 2002). Over the last few decades, a particular focus of ecological stoichiometry has been to document largescale patterns of, and the driving factors for, plant carbon: nitrogen: phosphorus (C:N:P) stoichiometry (Güsewell 2004; Reich and Oleksyn 2004; He et al. 2006, 2008; Sardans et al. 2012). The relationship between leaf stoichiometry, geographic patterns, and climate factors have been studied in both global and regional scale. Geographical variation in foliar ecological stoichiometry is a challenging issue to plant ecologists (Chown et al. 2004; Reich and Oleksyn, 2004; Yang et al. 2015; Wang et al. 2019). Meanwhile, homeostasis $(\mathrm{H})$ of element composition is one of the central concepts of ecological stoichiometry, and its strength is related to the ecological strategy and adaptability of the species (Sterner and Elser 2002; Persson et al. 2010). Stoichiometric homeostasis can help predict the strategies used by different plant species to cope with limited resources (Sterner and Elser 2002; Hessen et al. 2004). The nutrient conservatism of high $\mathrm{H}$-species could be an important mechanism contributing to their success, particularly in natural (unmodified) terrestrial ecosystems, where nutrient supply is often limiting and 
highly variable (Elser et al. 2010, Yu et al. 2010). Indeed, the stoichiometric homeostasis of plants varied with species, growth stages, and element types (Peng et al. 2016; Yan et al. 2016; Yu et al. 2011, 2015).

Stellera chamaejasme L., a toxic perennial weed, has been established and is now abundant in the alpine meadow on the eastern Tibetan Plateau and typical steppe on eastern Inner Mongolia Plateau of China (Sun et al. 2009; Guo et al. 2019). It has become one of the most serious weeds threatening a wide range of grasslands (Liu et al. 2004). Much attention has been given to S. chamaejasme because of its potential hazards on the grassland ecological safety and its impact on animal husbandry sustainability (Li et al. 2016; Jin et al. 2018; Guo et al. 2019; He et al. 2019; Ma et al. 2020). Despite this, no similar phylogeographical study had ever been conducted on $S$. chamaejasme. Plant nutrient and stoichiometry are key foliar traits with great ecological importance, but existing publications provide limited insight into biogeographic leaf nutrient and stoichiometry patterns for S. chamaejasme (Guo et al. 2019; Sun et al. 2009). As habitat heterogeneity tends to increase with geographical distance, wide-ranging species can usually use a wide array of resources and tolerate broad environmental conditions or physiological stresses and flourish over a larger area (Geng et al. 2011; Zhang et al. 2013). Recent studies have assumed that wide-ranging species always have stronger homeostasis or weak relationship in nutrient concentrations than narrow-ranging species in response to environmental factors (e.g. soil fertility) (Yu et al. 2010; Geng et al. 2011). Accordingly, we naturally associate the widespread of S. chamaejasme with its stoichiometric homeostasis and understand its distribution and invasiveness considering the stoichiometric homeostasis.

Several studies on a regional and global scale reported that changes of plant leaf $\mathrm{N}$ and $\mathrm{P}$ element stoichiometry are associated with many biotic and abiotic factors, including climate variables, soil properties, species, and plant functional groups (Güsewell 2004; He et al. 2006, 2008; Ordoñez et al. 2009; Zhang et al. 2019; Sun et al. 2017; Yang et al. 2015). However, species are commonly collected from a few individuals from one or a few populations and averaged at the population or species level, disregarding the intraspecific variability (Albert et al. 2010). Investigating the geographic variation within species can help to uncover the mechanism of relationships between plant tissue nutrients and environments (Hu et al. 2017), which exclude the confounding effects of taxonomic and phylogenetic structure like those found to influence the geographic patterns in leaf nutrients, and their linkages to climate and soil. Since relationships between environment and plant traits along environmental gradients could be presented as evidence of environmental control over species distribution, examining plantenvironment (e.g. climate and soil nutrient availability) interactions may provide some insights into the underlying mechanism of $S$. chamaejasme distribution in degraded grasslands. However, no studies have yet incorporated information on geographic patterns in leaf stoichiometry of $S$. chamaejasme in relation to environmental factors.

This study assesses the stoichiometry and patterns of $S$. chamaejasme leaves in degraded grasslands across northern China. The distinct habitats of Qinghai-Tibetan Plateau (QT) and Inner Mongolia Plateau (IM) provide a unique opportunity to test whether there are significant differences in leaf stoichiometry under different environmental conditions and to examine how and to what extent soil and climate modify 
leaf stoichiometry of $S$. chamaejasme across degraded grasslands. In general, most researchers focused on the roles of $\mathrm{C}, \mathrm{N}$, and $\mathrm{P}$ stoichiometry in the ecological process from individuals to ecosystems, but potassium $(K)$ is an essential macronutrient that has been partly overshadowed by $C, N$, and $P$ (Reich and Oleksyn 2004; Han et al. 2011; Sardans et al. 2012; Sardans and Peñuelas 2015). Our study also showed the K concentration of $S$. chamaejasme leaves, which broadens the contents of ecological stoichiometry. We hypothesized that 1) $S$. chamaejasme, a wide-spread weed, would exhibit small variation in leaf stoichiometry in relation to soil factors; in other words, $S$. chamaejasme may have stoichiometric homeostasis, and, 2) due to QT and IM differ in their limiting factors to vegetation, the relationship between $S$. chamaejasme and environmental factors may be related to different factors in the two habitats. To test our hypotheses, we first explored the overall biogeographic patterns of $\mathrm{C}, \mathrm{N}, \mathrm{P}$, and $\mathrm{K}$ stoichiometry of $S$. chamaejasme leaves from 29 sampling sites in two grassland ecosystems in northern China. We then disentangled the effects of climate and soil on the overall plant stoichiometry pattern and compared the difference between the two habitats.

\section{Materials And Methods}

\section{Study area}

Stellera chamaejasme is a poisonous plant widely distributed in degraded grasslands in China. The typical grassland of the Inner Mongolia Plateau (IM) and the alpine steppe of Qinghai-Tibetan Plateau (QT) are the two main grassland types and present a wide $S$. chamaejasme distribution. Twenty-nine sites were selected (10 sites in IM, 19 sites in QT, Fig. 1), extending from longitude 99.68 to $118.16^{\circ} \mathrm{E}$ and latitude 33.35 to $44.77^{\circ} \mathrm{N}$, along with altitudes ranging from 1060 to $3500 \mathrm{~m}$ (Supplementary 1). The mean annual temperature (MAT) and mean annual precipitation (MAP) ranged from 1.29 to $8.19^{\circ} \mathrm{C}$ and 143.84 to $587.53 \mathrm{~mm}$, respectively.

\section{Plant and soil sampling}

Field measurements were conducted in June-July 2019, which was the vigorous growth stage for $S$. chamaejasme. At least $30 \mathrm{~S}$. chamaejasme plants were randomly collected in each sampling site, then were subdivided into three subsamples, and the leaves of the subsamples were mixed into a composite sample. The samples were ground into fine powder for testing the content of elements (carbon, nitrogen, phosphorus, potassium). Concentrations of total C (LC) and total N (LN) of the S. chamaejasme leaves were determined sequentially by a FLASH 2000 elemental analyzer (Thermo Fisher Scientific, MA, USA). Total leaf $\mathrm{P}(\mathrm{LP})$ and $\mathrm{K}(\mathrm{LK})$ content were determined by using an AA-6300 Atomic absorption spectrophotometer (Shimadzu, Japan).

Three soil samples (0-15 cm in depth) were collected from each sample site. Each sample was thoroughly mixed and air-dried. Roots in the soil were removed by hand and passed through a 100-mesh sieve. Then, the soil was analysed for soil carbon (SC), nitrogen (SN), phosphorus (SP), potassium (SK), ammonium nitrogen (SAN), nitrate-nitrogen (SNN), available potassium (SAK), available phosphorus (SAP), the potential of hydrogen ( $\mathrm{pH})$, electrical conductivity (Ec), and water content (WC). Soil 
physicochemical properties were measured as by Bao (2000), SC and SN by the FLASH 2000 elemental analyzer, $\mathrm{SK}$ by $\mathrm{NaOH}$ fusion-flame photometry, SP by NaOH fusion-Mo/Sb colorimetry, SAN and SNN by Auto Discrete analyzer, and SAK were determined by the flame atomic absorption spectrophotometer. To measure SAP, air-dried and pre-weighed soil was extracted using $0.5 \mathrm{~mol} \mathrm{~L}^{-1} \mathrm{NaHCO}_{3}$ and $\mathrm{P}$ concentration in the extract was determined by the ammonium molybdate method. Soil pH was measured in a 1:2.5 soil:water suspension, and soil Ec was measured using a conductivity meter. Soil water contents were determined gravimetrically by oven-drying subsamples at $105^{\circ} \mathrm{C}$ for $24 \mathrm{~h}$.

\section{Data Analysis}

The means, standard deviations (SD), coefficients of variation (CV), maximum and minimum of leaf element concentrations and their ratios, and soil physicochemical properties were calculated for all sites, regions (Inner Mongolia and Qinghai Tibet). The data exhibited significant heteroscedasticity and nonnormal distributions. Thus, these variables were transformed using the natural logarithm before analysis to eliminate outliers or homogeneity of variances. Differences between QT and IM were evaluated by Independent-Samples T Test.

We calculated $\mathrm{H}$ according to the model: $\mathrm{y}=\mathrm{cx}^{1 / \mathrm{H}}$, where $\mathrm{y}$ is the leaf element concentration of $S$. chamaejasme, $\mathrm{x}$ is the total nutrient contents or available nutrients in the soil, and $\mathrm{c}$ is a constant. The values of $\mathrm{H}$ and $\mathrm{c}$ were obtained when we analyzed the relationship between $\mathrm{y}$ and $\mathrm{x}$ using regression analysis. A high value of $\mathrm{H}$ indicates strong stoichiometric homeostatic regulation.

In order to determine the influence of climate factors, we obtained raw daily precipitation and temperature data (2010-2019) from the China Meteorological Administration and calculated annual precipitation and temperature using the Kriging interpolation method in ArcGIS (ESRI (Environmental Systems Research Institute), Redlands, CA, USA). Therefore, climate data for MAT, MAP for the sample sites were obtained. Regression analyses were performed to determine the correlation of leaf element contents and climate factors (MAT, MAP). Scatter plots were used to visualize the relationships among leaf element contents and climate factors (MAT, MAP), and appropriate regression equations were developed.

Partial least squares path modeling (PLS-PM) was employed to explore the direct, indirect, and interactive effects between all environmental variables for leaf element contents (The R package pls pm (0.4.9)). The model included the following variables: Leaf elements (LP, LK), climate factors (MAT, MAP), and soil factors (SK, SAK,SNN, and SpH for LP in IM, SP, SAN and SNN for LK in IM, SP, SAP, SNN and SpH for LP in QT, SC, SK, SAP, SWC, and SpH for LP in QT), after testing for collinearity of soil factors with the multivariate analog of Levene's test using the "betadisper" function in the vegan package. Indirect effects are defined as multiplied path coefficients between predictor and response variables, including all possible paths excluding the direct effect. The final model was chosen among all constructed models based on the Goodness of Fit (GOF) statistic according to the model`s overall predictive power.

\section{Results}




\section{Pattern of leaf ecological stoichiometry and soil physicochemical properties of $S$. chamaejasme}

The mean value (mean), standard deviation (SD), coefficients of variation (CV\%), maximum and minimum of leaf ecological stoichiometry of $S$. chamaejasme, and soil chemical and physical properties were listed in Table 1, and a comparison was made between two main habitats of $S$. chamaejasme (Fig. 2). Leaf $C, N, P, K$ and $C: N, C: P, N: P$ of $S$. chamaejasme varied gently across all study sites. The mean leaf $C, N, P$, and $K$ were $498.60 \mathrm{~g} \mathrm{~kg}^{-1}, 19.95 \mathrm{~g} \mathrm{~kg}^{-1}, 2.15 \mathrm{~g} \mathrm{~kg}^{-1}$, and $6.00 \mathrm{~g} \mathrm{~kg}^{-1}$, respectively, and $C V \%$ of leaf $P$ was the largest. Moreover, the mean leaf C:N ratio was 25.46, C:P ratio 246.22, N:P ratio 9.84.

Inconsistent with the pattern of leaf results, soil physicochemical properties of $S$. chamaejasme invaded area varied wildly. Soil C, N, P, and K exhibited large variations, primarily ranging c. $5.87-84.74 \mathrm{~g} \mathrm{~kg}^{-1}$ for C; 0.24-7.43 $\mathrm{g} \mathrm{kg}^{-1}$ for $\mathrm{N}, 0.20-0.82 \mathrm{~g} \mathrm{~kg}^{-1}$ for $\mathrm{P}$, and $0.95-30.55 \mathrm{~g} \mathrm{~kg}^{-1}$ for $\mathrm{K}$. Variation in soil $\mathrm{K}$ content across all study sites was about 32 times (Max/Min), which was the most variable element among the four total elements. Soil mean C:N, N:P, and C:P ratios were 13.99, 77.50, and 6.34, respectively. For available soil nutrients, soil NN variation was considerably larger than that for the AP, AK, and AN content, as evidenced by coefficients of variation (CVs) (Table 1). Similarly, soil WC, pH, and Ec showed a greater variation throughout the sampling areas.

When compared leaf element contents of $S$. chamaejasme in QT and IM, we found that only leaf K concentrations were significantly different between the two habitats, which was greater in QT. Moreover, most soil physicochemical properties were higher in QT than those in IM, except SAN, SNN, and Ec.

Specifically, soil P, K, SAP, WC, and pH were significantly higher in QT than IM, but soil Ec was significantly lower in QT.

Table 1 Descriptive statistics for regional S. chamaejasme leaf ecological stoichiometry and soil physicochemical properties in Northern China 


\begin{tabular}{|c|c|c|c|c|c|c|}
\hline \multicolumn{2}{|c|}{ Overall $(n=29)$} & \multirow{2}{*}{$\begin{array}{l}\text { Mean } \\
498.60\end{array}$} & \multirow{2}{*}{$\begin{array}{l}\text { SD } \\
22.07\end{array}$} & \multirow{2}{*}{$\begin{array}{l}\mathrm{CV}(\%) \\
4.43\end{array}$} & \multirow{2}{*}{$\begin{array}{l}\text { Maximum } \\
536.20\end{array}$} & \multirow{2}{*}{$\begin{array}{l}\text { Minimum } \\
451.33\end{array}$} \\
\hline Leaf & $\mathrm{C}\left(\mathrm{g} \mathrm{kg}^{-1} \mathrm{u}\right.$ & & & & & \\
\hline & $N\left(\mathrm{~g} \mathrm{~kg}^{-1} \mathrm{\square}\right.$ & 19.95 & 2.09 & 10.48 & 23.48 & 15.29 \\
\hline & $P\left(\mathrm{~g} \mathrm{~kg}^{-1} \square\right.$ & 2.15 & 0.52 & 24.19 & 3.19 & 1.40 \\
\hline & $\mathrm{K}\left(\mathrm{g} \mathrm{kg}^{-1} \mathrm{\square}\right.$ & 6.57 & 1.18 & 17.96 & 9.08 & 4.15 \\
\hline & C:N & 25.46 & 2.51 & 9.86 & 33.17 & 22.49 \\
\hline & $C: P$ & 246.22 & 61.75 & 25.08 & 359.69 & 154.99 \\
\hline & $\mathrm{N}: \mathrm{P}$ & 9.84 & 2.61 & 26.52 & 14.89 & 5.29 \\
\hline \multirow[t]{14}{*}{ Soil } & $C\left(\mathrm{~g} \mathrm{~kg}^{-1} \square\right.$ & 46.11 & 21.63 & 46.91 & 84.74 & 5.87 \\
\hline & $N\left(\mathrm{~g} \mathrm{~kg}^{-1} \square\right.$ & 3.75 & 1.70 & 45.24 & 7.43 & 0.24 \\
\hline & $P\left(g_{k g}^{-1} \square\right.$ & 0.57 & 0.17 & 29.82 & 0.82 & 0.20 \\
\hline & $\mathrm{K}\left(\mathrm{g} \mathrm{kg}^{-1} \mathrm{q}\right.$ & 20.80 & 5.86 & 28.17 & 30.55 & 0.95 \\
\hline & C:N & 13.99 & 8.08 & 57.70 & 45.21 & 7.72 \\
\hline & $\mathrm{C}: \mathrm{P}$ & 77.50 & 25.49 & 32.89 & 130.24 & 24.87 \\
\hline & $N: P$ & 6.34 & 2.17 & 34.15 & 10.50 & 0.61 \\
\hline & $\mathrm{AP}\left(\mathrm{mg} \mathrm{kg}^{-1}\right)$ & 5.29 & 1.96 & 37.00 & 10.42 & 2.36 \\
\hline & $\mathrm{AK}\left(\mathrm{mg} \mathrm{kg}^{-1}\right)$ & 175.91 & 96.39 & 54.80 & 407.33 & 42.33 \\
\hline & AN $\left(\mathrm{mg} \mathrm{kg}^{-1}\right)$ & 19.17 & 7.89 & 41.16 & 42.43 & 7.64 \\
\hline & $\mathrm{NN}\left(\mathrm{mg} \mathrm{kg}^{-1}\right)$ & 14.12 & 14.20 & 100.57 & 83.35 & 3.13 \\
\hline & WC & 0.18 & 0.09 & 50.00 & 0.35 & 0.03 \\
\hline & $\mathrm{pH}$ & 7.90 & 0.51 & 6.46 & 8.81 & 6.82 \\
\hline & $\operatorname{Ec}\left(\mu \mathrm{sm}^{-1}\right)$ & 247.21 & 221.21 & 89.48 & 874.50 & 40.00 \\
\hline
\end{tabular}

Note: SD is standard deviations and CV is coefficient of variation

\section{Ecological stoichiometry homeostasis of S. chamaejasme in degraded grassland}

The relationships between leaf elements of $S$. chamaejasme and soil were evaluated using the homeostasis index $(\mathrm{H})$, obtained from the homeostasis model. In Fig. 3, $\mathrm{H}$ of $\mathrm{C}$ and $\mathrm{N}$ were 0 , indicating that the leaf of $S$. chamaejasme could not retain carbon and nitrogen. The $\mathrm{H}$ of AN and NN were 0 , showing the stronger effect of both forms of soil inorganic nitrogen on leaf nitrogen of S. chamaejasme. 
Additionally, $\mathrm{H}$ of $\mathrm{P}$ and $\mathrm{K}$ were higher than 1 , and $\mathrm{H}_{\mathrm{K}}$ (13.16) was greater than $\mathrm{H}_{\mathrm{P}}$ (4.17). Likewise, $\mathrm{H}_{\mathrm{AP}}$ (4.17) was smaller than $\mathrm{H}_{\mathrm{AK}}$ (13.21) in $S$. chamaejasmeleaves. In summary, the $\mathrm{H}$ index of $S$. chamaejasme changed between 4.17 and 13.21 .

\section{Spatial variation of leaf elements of $S$. chamaejasme in relation to climatic factors}

No significant relationships among leaf $\mathrm{C}$ and $\mathrm{N}$ content and climatic factors (MAT and MAP) were found using data for all sample sites or regions. For all study sites, only leaf $K$ content was correlated with climate factors ( $P \otimes 0.001)$ with greater $\mathrm{K}$ with increasing MAT (Fig.4). For the regions, it should be noted that in IM, the relationship between leaf $P$ and climatic factors was significant, but $K$ was not; on the contrary, the K content of $S$. chamaejasme leaves was related to climatic factors but $P$ was not in QT. To be specific, leaf $P$ concentration increased with increasing MAT and MAP in IM. Moreover, with increasing MAT, leaf $K$ had an increasing trend, but increasing MAP showed an opposite trend in QT.

\section{Relative roles of soil and climatic factors}

Both P and K content of $S$. chamaejasme leaves were affected by soil and climatic factors simultaneously. Thus a more in-depth analysis using partial least squares path modeling revealed direct and indirect effects of the environmental drivers on leaf $\mathrm{P}$ and $\mathrm{K}$ content of $\mathrm{S}$. chamaejasme in different regions (Fig. 5). The standardized direct, indirect, and total effects of soil and climate variables on the leaf $\mathrm{P}$ and $\mathrm{K}$ in QT and IM are presented in Table 2. Firstly, the influence of climatic factors on soil were bigger in IM than that in QT, but the effect of climatic factors on soil was significant on LP in IM. Secondly, we found that soil factors had significant effect only on leaf P in QT, however, the effects of soil factors on LP or LK in IM and LK in QT were insignificant. Thirdly, the direct effect of climate factors on LP or LK in IM and LK in QT were greater than the indirect, while the direct effect on LP in QT was less than the indirect impact. These results suggest that LP or LK were affected by different mechanisms in QT and IM regions. Moreover, the goodness of fit (GOF) was 0.3205 and 0.3556 for LP and LK in QT, respectively, and 0.5490 and 0.4431 in IM. The relatively low predictive power of the model of QT suggested that most variation remained unexplained.

Table 2 Summary of the total effects on the leaf $\mathrm{P}$ and $\mathrm{K}$ of $S$. chamaejasme in Qinghai Tibet Plateau (QT) and Inner Mongolia Plateau (IM) 


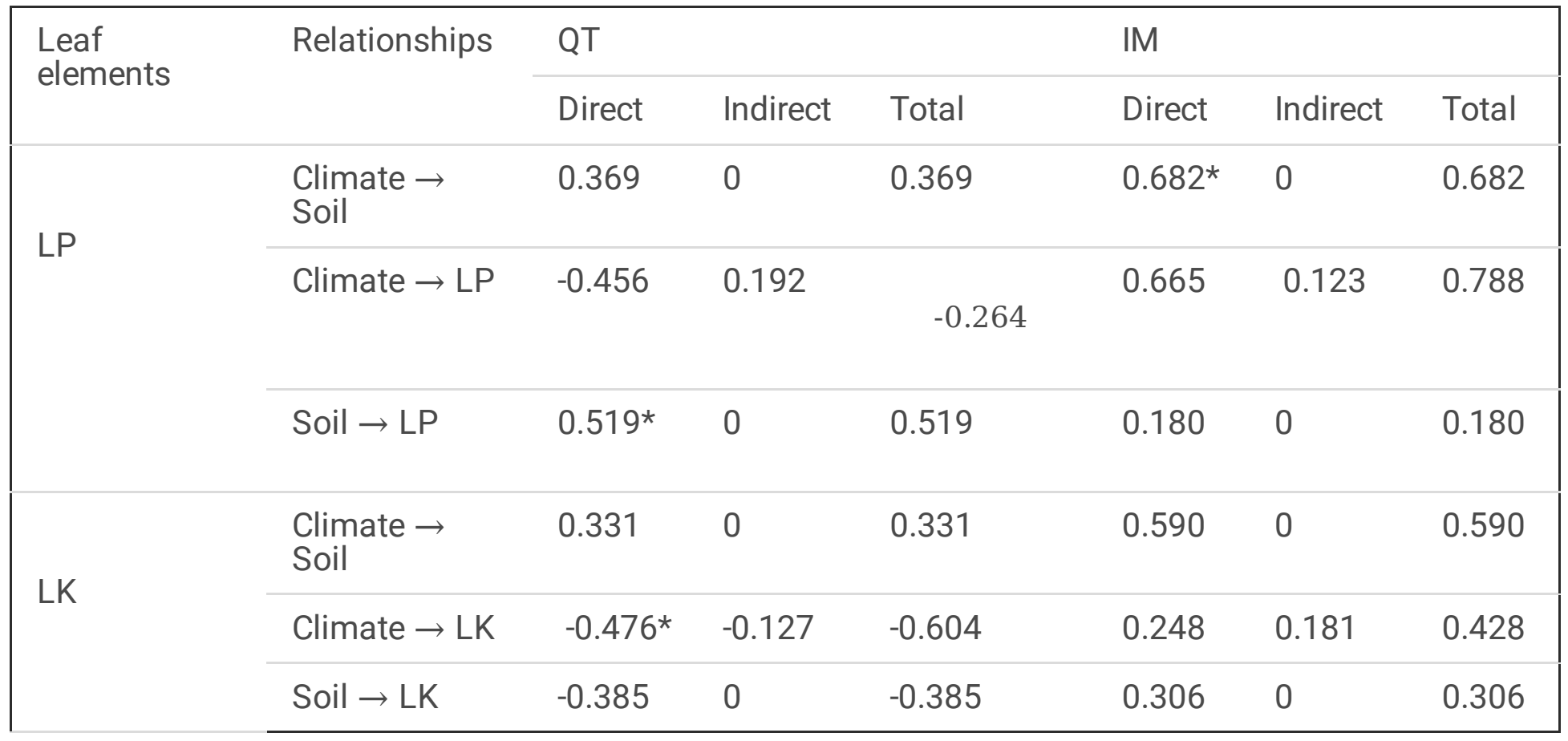

\section{Discussion}

Overall patterns of leaf ecological stoichiometry and soil physicochemical properties of $S$. chamaejasme across northern China

The patterns of $\mathrm{N}$ and $\mathrm{P}$ status in plant biomass, and especially in leaves, have been intensely studied (Koerselman and Meuleman 1996; Reich and Oleksyn 2004; Han et al. 2005; He et al. 2006, 2008; Song et al. 2014; Fan et al. 2016), but few studies have attempted to document intraspecific leaf stoichiometry, especially for poisonous weeds in grasslands. This study presents, to our knowledge, the first analysis of leaf element concentrations (C, N, P, K) and ratios (C:N, C:P, N:P) of S. chamaejasme across degraded grassland in northern China. Our results show that leaf $C\left(498.60 \mathrm{~g} \mathrm{~kg}^{-1}\right), \mathrm{N}\left(19.95 \mathrm{~g} \mathrm{~kg}^{-1}\right)$, and $\mathrm{P}(2.15 \mathrm{~g}$ $\mathrm{kg}^{-1}$ ) of $S$. chamaejasme were higher than the mean value of all species in the China Grassland Transect (Fan et al. 2016), and there was no obvious difference between two habitats of $S$. chamaejasme. $\mathrm{N}$ and $\mathrm{P}$ are the most important limiting nutrients for primary productivity in terrestrial ecosystems (Elser et al. 2007), and a high concentration of $\mathrm{N}$ and $\mathrm{P}$ in $\mathrm{S}$. chamaejasme leaves means high nutrient uptake efficiency of $S$. chamaejasme in degraded grasslands, which could facilitate $S$. chamaejasme outcompete other species in nutrient-poor environments. Moreover, $\mathrm{K}$ is one of the essential macronutrients that play critical roles in various metabolic processes, but it has been partly overshadowed in ecological stoichiometry by nitrogen and phosphorus (Shin 2014; Adams and Shin 2014). Although most studies did not involve the $K$ content in plant leaves, it is worth noting that $K$ concentrations of $S$. chamaejasme were significantly greater in QT than that in IM. The reason may be that the content of nutrients in plants can be constrained by nutrient supply in the soil, and the content of soil $\mathrm{K}$ is significantly higher in QT, therefore generating this difference. The leaf C:N ratio of $S$. 
chamaejasme was 25.46, C:P ratio 246.22, N:P ratio 9.84. Generally, it is not uncommon that using N:P ratios of plant biomass as indicators of $\mathrm{N}$ or $\mathrm{P}$ limitation in various studies (Koerselman and Meuleman 1996; Tessier and Raynal 2003). The low N/P ratio in S. chamaejasme might imply that its growth is restricted by N, which was consistent with the results reported by Guo et al. (2019).

We found that $S$. chamaejasme could survive in a soil environment with considerable variation, which is consistent with the fact that $S$. chamaejasme is wide-ranging species with a wide geographic range in China grassland (Zhang et al. 2015). The soil condition for S. chamaejasme growth varies considerably from site to site. Soil physicochemical properties varied with a difference of more than 10 times between the maximum and the minimum included C (14.43 times), N (30.94 times), $\mathrm{K}$ (32.27 times), NN (26.66 times), WC (10.60 times), Ec (21.86 times). Moreover, one sampling site (Haiyan in QT) showed the

greatest soil physicochemical properties. For example, the content of soil $P$ was lowest $\left(0.20 \mathrm{~g} \mathrm{~kg}^{-1}\right)$, and soil WC was the minimum (0.03), but pH reached a maximum (8.81), indicating $S$.

chamaejasme could tolerate an extreme environment. This may provide a competitive advantage for $S$. chamaejasme against other plant species and help explain its rapidly expansion in degraded grasslands. Additionally, we also found that the $C V$ of NN was $100.57 \%$, greater than for AN (41.16\%), indicating that S. chamaejasme was less sensitive to the NN variation.

Generally, Tibetan alpine grasslands and Inner Mongolian temperate grasslands, which have different limiting factors, are both zonal grassland types in China ( $\mathrm{Li}$ et al. 2020). Alpine grasslands are mainly limited by low temperatures in the growing season, while temperate grasslands are affected by drought (Fan et al. 2016). Accordingly, our analysis indicated that some soil physicochemical properties of $S$. chamaejasme for the regions were significantly different. Soil WC and pH for Qinghai-Tibet were significantly higher, and Ec lower than those for Inner Mongolia. However, apart from SP, SK and SAP, soil $\mathrm{C}$ and $\mathrm{N}$ concentrations and other soil available nutrients (AN, NN, AK) for the regions were insignificantly different. These findings suggest that climate imposes important controls on soil nutrients.

\section{Relationships between leaf $\mathrm{C}, \mathrm{N}, \mathrm{P}$ and $\mathrm{K}$ and environmental variables}

Plant nutrient concentrations and their correlations with soil nutrient conditions are considered effective tools for exploring plant adaptation and resource utilization strategies in a severe environment (Ordoñez et al. 2009; Hong et al. 2015; Geng et al. 2011). Stoichiometric homeostasis (H) is the ability of plants to maintain their element composition relatively stable regardless of changes in nutrient availability via various physiological mechanisms (Sterner \& Elser 2002; Persson et al., 2010). The degree of stoichiometric homeostasis can be indicated by the homeostatic coefficient $(H)$, which reflects the ability of plants to maintain a stable nutrient composition regardless of changes in environmental nutrients (Sterner and Elser 2002; Hessen et al. 2004; Giordano 2013; Wang et al. 2019). It is well known that stoichiometric homeostasis had been reported in dominant palatable species ( $\mathrm{Li}$ et al. 2016; Yu et al. 2015; Peng et al. 2016) in grasslands. However, this has not been established in unpalatable species. Since poisonous plants represent the majority of the plant species detected after grasslands have been degraded, reveal the eco-physiology characteristics of poisonous weeds will help us better understand 
why poisonous weeds can spread widely on degraded grasslands. We found $\mathrm{H}_{\mathrm{C}}$ and $\mathrm{H}_{\mathrm{N}}$ of $S$. chamaejasme were 0 , indicating that $S$. chamaejasme could not maintain carbon and nitrogen internally. Compared with other grassland species, $S$. chamaejasme had no $\mathrm{H}_{\mathrm{N}}$, which was different from previously reported results for other species (Wu and Wang 2019; Yu et al. 2011). Our data clearly show that the stoichiometric homeostasis coefficient of $\mathrm{P}\left(\mathrm{H}_{\mathrm{P}}\right)$ of $S$. chamaejasme was higher than $\mathrm{N}\left(\mathrm{H}_{\mathrm{N}}\right)$, indicating $S$. chamaejasme was relatively less sensitive responses to soil $\mathrm{P}$ than soil $\mathrm{N}$. However, $\mathrm{H}_{\mathrm{N}}$ was consistently higher than $\mathrm{H}_{\mathrm{P}}$ at the levels of community, family, and species in China reported by previous studies (Peng et al. 2016; Yu et al. 2015). Like many other terrestrial ecosystems, grassland ecosystems face an ongoing increase of atmospheric nitrogen deposition in recent decades (Menge \& Field, 2007). The increase of $\mathrm{N}$ availability in the soil leads to ecosystems limited by $\mathrm{N}$ have gradually transformed to $\mathrm{P}$ limitation or other elements (Galloway et al. 2008; Lebauer and Treseder 2008). Thus $S$. chamaejasme with $\mathrm{H}_{\mathrm{P}}$ could survive outstandingly than species without $\mathrm{H}_{\mathrm{P}}$ in the future P-limited surroundings. Moreover, although globally $\mathrm{N}$ and $\mathrm{P}$ are considered of paramount importance to plant function, it is widely known that many other elements are also important in specific contexts or regions (Han et al. 2011). We also found that $H_{K}$ was greater than $H_{P}$, implying $K$ could be used as another important element that indicates the degree to which an organism maintains homeostasis.

Our results indicate that in the macro scale, leaf $\mathrm{C}$ and $\mathrm{N}$ do not directly correlate with meteorological factors (MAT and MAP), which is in agreement with previous studies conducted in the grassland biomes of China (He et al. 2006). The weak relationships observed between leaf $C, N$, and climatic variables may result from plant growth, development, metabolism, phenological and life-history traits rather than from the specific geographic environment. On the contrary, there were close relationships between leaf $P$ and $K$ and climatic factors (Fig. 4). The relationship between leaf $P$ and climate factors was significant only in $\mathrm{IM}$, and the K content of $S$. chamaejasme leaves was significantly related to climate factors only in QT. We noticed that the correlation of leaf $P$ and MAP $\left(R^{2}=0.5523\right)$ was greater than the relationship between $P$ and MAT $\left(R^{2}=0.4886\right)$ in IM, and the relationship between $K$ and MAT $\left(R^{2}=0.3338\right)$ was greater than that with MAP $\left(R^{2}=0.2920\right)$ in QT. These again reflect the different limiting factors of plant growth in different regions (Fan et al. 2016). It is a reasonable assumption that precipitation is a more important limiting factor than the temperature for vegetation growth in arid and semi-arid regions like Inner Mongolian Plateau temperate grasslands. In contrast, the temperature is more likely to have a greater effect on leaf element concentrations than precipitation in Qinghai Tibet Plateau alpine grasslands with high-altitude and low temperature. We also found that only LK was negative related with MAP in QT. In fact, $K$ leaches more easily from leaves than $N$ and $P$ (Sardans and Peñuelas 2015); hence it is easy to ascertain the increasement of MAP in the studies leading more leaf leaching of $\mathrm{K}$ in $\mathrm{S}$. chamaejasme.

To explore complex relationships between soil and climatic factors on leaf $\mathrm{P}$ and $\mathrm{K}$ contents of $S$. chamaejasme, we conducted a PLS-PM analysis. We found soil exerted a significant effect on leaf $P$ and climate affected leaf $P$ and $K$ both directly and indirectly in QT, while LP appeared to be limited mainly by climatic factors and via direct ways and LK was not affected significantly by any environmental factors in IM. More specifically, climatic factors had an significant influence on soil in IM. Meanwhile, climatic 
variables had stronger direct effects on LP than the indirect effects in IM. This was contradicting our knowledge that climate factors often affect leaf elements through their influence on soil nutrient status (Luo et al. 2021). However, the arid conditions of the Inner Mongolia Plateau (Arid and Semi-Arid Areas) have no doubt restricted grassland plants growth by insufficient water, and Zhang et al found that drought has become the primary natural disaster threatening to Inner Mongolia grassland ecosystem (Zhang et al. 2009). In addition, climatic factors affected soil state insignificantly and directly or indirectly influenced leaf $\mathrm{P}$ or $\mathrm{K}$ in QT. Soil factors had significant influence over LP and the influence of climatic variables on LK was significant, indicating the effects of climatic factors and soil factors on LP or LK occurred separately. Our model suggests that underlying mechanisms behind the LP or LK content were different in the two habitats.

In addition, species natural habitats will be subject to more disturbances in the future due to climate change and habitat degradation caused by intensive anthropogenic activities (Wei et al. 2019; Chen et al. 2020). In future works, continuing wide-scale sampling and considering the influence of human activities are required to further develop a deeper understanding of the geographic patterns in S. chamaejasme.

\section{Conclusion}

Our study is, to our knowledge, the first to comprehensively document the chemistry of multiple mineral elements $(\mathrm{C}, \mathrm{N}, \mathrm{P}, \mathrm{K})$ of $\mathrm{S}$. chamaejasme leaves and its surrounding soil physiochemical properties and quantify the potential controls and variability at a large scale. We found that leaf $\mathrm{C}, \mathrm{N}$, and $\mathrm{P}$ of $S$. chamaejasme were higher than the national average of grassland species, and there was no obvious difference between the two habitats, but K concentrations were significantly greater in QT than that in IM. Inconsistent with the pattern of leaf results, soil physiochemical properties of $S$. chamaejasme invaded area varied wildly, and most of them were greater in QT. S. chamaejasme could survive in different soil environments, which supported the fact that wide-ranging species tend to be insensitive to variation in soil nutrient availability.

Based on the homeostasis model, our result clearly show that only the stoichiometric homeostasis of $\mathrm{P}$ and $\mathrm{K}$ in $\mathrm{S}$. chamaejasme across north China was observed, and $\mathrm{H}_{\mathrm{K}}$ was higher than $\mathrm{H}_{\mathrm{P}}$, which differs from previously reported results for other species. In addition, leaf $\mathrm{P}$ and $\mathrm{K}$ were affected by climatic variables. We found the relationship between leaf $P$ and climate factors was significant only in IM, while the $\mathrm{K}$ content was related significantly to climate factors only in QT.

In sum, both $\mathrm{C}$ and $\mathrm{N}$ content of $\mathrm{S}$. chamaejasme leaves were unaffected by any environmental factors, but $P$ and $K$ in the two habitats were influenced by different factors. This study demonstrates that soil exerted a significant effect on leaf $P$ and climate affected leaf $P$ and $K$ both directly and indirectly in QT, while LP appeared to be limited mainly by climatic factors and via direct ways and LK was not affected significantly by any environmental factors in IM by conducting a PLS-PM analysis. The study contributes to the understanding of biogeographic patterns and adaption strategy of S. chamaejasme in the degraded grasslands in China. 


\section{Declarations}

\section{Acknowledgements}

We thank Guoliang Wang, Huan Zhao, Jiahuan Li for for field assistance.

\section{Funding}

This research was supported by Beijing Science and Technology Project (Z181100009618031), Special Aid Fund for Qinghai Province (2020-QY-210), International Collaboration Fund of Department of Science and Technology of Shaanxi Province (2020KW-030).

\section{Conflicts of interest}

The authors declare that they have no known competing financial interests or personal relationships that could have appeared to influence the work reported in this paper.

\section{Availability of data and material (data transparency)}

All the data were summarized in the manuscript itself. Please contact the corresponding author regarding any additional queries related to the dataset generated and analyzed during the current study. The datasets in this study are available from the corresponding author on reasonable request.

\section{Code availability}

Not applicable.

\section{Authors' contributions}

LZ Guo and D Huang conceived the ideas and designed methodology; L Liu, HZ Meng, L Zhang $\$ and W He collected the data; LZ Guo and K Wang analysed the data; LZ Guo and D Huang led the writing of the manuscript; W He and VJ Silva reviewed and edited the manuscript. All authors contributed critically to the drafts and gave final approval for publication.

\section{Ethics approval}

The sampling of plant and soil did not require permission from any local or national authority as sampled. The sampled species are not classifed as endangered and are not under any protection in the sampled area.

\section{Consent to participate}

Not applicable.

\section{Consent for publication}


Not applicable.

\section{References}

1. Adams E, Shin R (2014) Transport, signaling, and homeostasis of potassium and sodium in plants. J Integr Plant Biol 56:231-249. https://doi.org/10.1111/jipb.12159

2. Albert CH, Thuiller W, Yoccoz NG, Soudant A, Boucher F, Saccone P, Lavorel S (2010) Intraspecific functional variability: extent, structure and sources of variation. J Ecol 98:604613. https://doi.org/10.1111/j.1365-2745.2010.01651.x

3. Bao SD (2000) Soil Agricultural Chemical Analysis, 3rd ed. China Agricultural Press, Beijing (in Chinese).

4. Chen JH, Yan F, Lu Q (2020) Spatiotemporal variation of vegetation on the Qinghai-Tibet plateau and the influence of climatic factors and human activities on vegetation trend (2000-2019). Remote Sens 12:3150. https://doi.org/10.3390/rs12193150

5. Chown SL, Gaston KJ, Robinson D (2004) Macrophysiology: largescale patterns in physiological traits and their ecological implications. Funct Ecol18:159-167. https://doi.org/10.1111/j.02698463.2004.00825.x

6. Elser JJ, Sterner RW, Gorokhova E, Fagan WF, Markow TA, Cotner JB, Harrison JF, Hobbie SE, Odell GM, Weider LW (2000) Biological stoichiometry from genes to ecosystems. Ecol Lett 3(6):54050. https://doi.org/10.1111/j.1461-0248.2000.00185.x

7. Elser JJ, Bracken MES, Cleland EE, Gruner DS, Harpole WS, Hillebrand H, Ngai JT, Seabloom, EW, Shurin JB, Smith JE (2007) Global analysis of nitrogen and phosphorus limitation of primary producers in freshwater, marine and terrestrial ecosystems. Ecol Lett 10:1135-

1142. https://doi.org/10.1111/j.1461-0248.2007.01113.x

8. Elser JJ, Fagan WF, Kerkhoff AJ, Swenson NG, Enquist BJ (2010) Biological stoichiometry of plant production: metabolism, scaling and ecological response to global change. New Phytol 186:593608. https://doi.org/10.1111/j.1469-8137.2010.03214.x

9. Fan JW, Harris W, Zhong HP (2016) Stoichiometry of leaf nitrogen and phosphorus of grasslands of the Inner Mongolian and Qinghai-Tibet Plateaus in relation to climatic variables and vegetation organization levels. Ecol Res 31(6):821-829. https://doi.org/10.1007/s11284-016-1392-5

10. Galloway JN, Townsend AR, Erisman JW, Bekunda M, Cai Z, Freney JR, Martinelli LA, Seitzinger SP, Sutton MA (2008) Transformation of the nitrogen cycle: recent trends, questions, and potential solutions. Science 320(5878):889-892. https://doi.org/ 10.1126/science.1136674

11. Geng Y, Wang ZH, Liang CZ, Fang JY, Baumann F, Kuhn P, Scholten T, He JS (2011) Effect of geographical range size on plant functional traits and the relationships between plant, soil and climate in Chinese grasslands. Glob Ecol Biogeogr 21(4):416-427. https://doi.org/10.1111/j.14668238.2011.00692.x 
12. Giordano M (2013) Homeostasis: An underestimated focal point of ecology and evolution. Plant Sci 211:92-101. https://doi.org/10.1016/j.plantsci.2013.07.008

13. Guo LZ, Li JH, He W, Liu L, Huang D, Wang K (2019) High nutrient uptake efficiency and high water use efficiency facilitate the spread of Stellera chamaejasme L. in degraded grasslands. BMC Ecol 19(1):50. https://doi.org/10.1186/s12898-019-0267-3

14. Güsewell S (2004) N:P ratios in terrestrial plants: variation and functional significance. New Phytol 164(2):243-266. https://doi.org/10.1111/j.1469-8137.2004.01192.x

15. Han WX, Fang JY, Reich PB, Woodward FI, Wang ZH (2011) Biogeography and variability of eleven mineral elements in plant leaves across gradients of climate, soil and plant functional type in China. Ecol Lett 14(8):788-796. https://doi.org/10.1111/j.1461-0248.2011.01641.x

16. Han WX, Fang JY, Guo DL, Zhang Y (2005) Leaf nitrogen and phosphorus stoichiometry across 753 terrestrial plant species in China. New Phytol 168(2):377-385. https://doi.org/10.1111/j.14698137.2005.01530.x

17. Hessen DO, Agren GI, Anderson TR, Elser JJ, De Ruiter PC (2004) Carbon sequestration in ecosystems: the role of stoichiometry. Ecology 85(5):1179-1192. https://doi.org/10.1890/02-0251

18. He JS, Wang L, Flynn DFB, Wang XP, Ma WH, Fang JY (2008) Leaf nitrogen:phosphorus stoichiometry across Chinese grassland biomes. Oecologia 155:301-310. https://doi.org/10.1007/s00442-007-0912-y

19. He JS, Fang JY, Wang ZH, Guo DL, Flynn DFB, Geng Z (2006) Stoichiometry and large-scale patterns of leaf carbon and nitrogen in the grassland biomes of China. Oecologia 149:115122. https://doi.org/10.1007/s00442-006-0425-0

20. He W, Detheridge A, Liu YM, Wang L, Wei HC, Griffith GW, Scullion J, Wei YH (2019) Variation in Soil Fungal Composition Associated with the Invasion of Stellera chamaejasme L. in Qinghai-Tibet Plateau Grassland. Microorganisms 7(12):587. https://doi.org/10.3390/microorganisms7120587

21. Hong JT, Wang XD, Wu JB (2015) Effects of soil fertility on the N:P stoichiometry of herbaceous plants on a nutrient-limited alpine steppe on the northern Tibetan Plateau. Plant Soil 391(1-2):179194. https://doi.org/10.1007/s11104-015-2416-6

22. Hu YK, Zhang YL, Liu GF, Pan X, Yang XJ, Li WB, Dai WH, Tang SL, Xiao T, Chen LY (2017) Intraspecific $\mathrm{N}$ and $\mathrm{P}$ stoichiometry of Phragmites australis: geographic patterns and variation among climatic regions. Sci Rep 7:43018. https://doi.org/10.1038/srep43018

23. Jin H, Yang XY, Liu RT, Yan ZQ, Li XD, Li XZ, Su AX, Zhao YH, Qin B (2018) Bacterial community structure associated with the rhizosphere soils and roots of Stellera chamaejasme L. along a Tibetan elevation gradient. Ann Microbiol 68(5):273-286. https://doi.org/10.1007/s13213-018-1336-0

24. Koerselman W, Meuleman AFM (1996) The vegetation N : P ratio: a new tool to detect the nature of nutrient limitation. J Appl Ecol 33(6):1441-1450. https://doi.org/10.2307/2404783

25. Lebauer DS, Treseder KK (2008) Nitrogen limitation of net primary productivity in terrestrial ecosystems is globally distributed. Ecology 89(2):371-379. https://doi.org/ 10.1890/06-2057.1 
26. Li YF, Li QY, Guo DY, Liang S, Wang YJ (2016) Ecological stoichiometry homeostasis of leymus chinensis in degraded grassland in western Jilin Province, NE China. Ecol Eng 90:387391. http://doi.org/10.1016/j.ecoleng.2016.01.079

27. Li JZ, Liu YM, Mo CH, Wang L, Pang GW, Cao MM (2016) IKONOS Image-based extraction of the distribution area of Stellera chamaejasme L. in qilian county of Qinghai province, China. Remote Sens 8(2):148. https://doi.org/10.3390/rs8020148

28. Li LH, Chen JQ, Han XG, Zhang WH, Shao CL (2020) Grassland ecosystems of China: a synthesis and resume. Springer Nature Singapor.

29. Liu Y, Long R, Yao T (2004) Research progress on Stellera chamajasme L. in grassland. Pratacultural Science 21:55-61 (in Chinese)

30. Luo Y, Peng QW, Li KH, Gong YM, Liu YY, Han WX (2021) Patterns of nitrogen and phosphorus stoichiometry among leaf, stem and root of desert plants and responses to climate and soil factors in Xinjiang, China. Catena 199:105100. https://doi.org/10.1016/j.catena.2020.105100

31. Ma JG, Bowatte S, Wang YF, Newton P, Hou FJ (2020) Differences in soil ammonia oxidizing bacterial communities under unpalatable ( Stellera chamaejasme L.) and palatable (Elymus nutans Griseb.) plants growing on the Qinghai Tibetan Plateau. Soil Biol Biochem

144:107779. https://doi.org/ 10.1016/j.soilbio.2020.107779

32. Menge DN, Field CB (2007) Simulated global changes alter phosphorus demand in annual grassland. Glob Chang Biol 13(12):2582-2591. https://doi.org/10.1111/j.1365-2486.2007.01456.x

33. Ordoñez JC, Van Bodegom PM, Witte JPM, Wright IJ, Reich PB, Aerts R (2009) A global study of relationships between leaf traits, climate and soil measures of nutrient fertility. Glob Ecol Biogeogr 18(2):137-149. https://doi.org/ 10.1111/j.1466-8238.2008.00441.x

34. Peng HY, Chen YH, Yan ZB, Han WX (2016) Stage-dependent stoichiometric homeostasis and responses of nutrient resorption in Amaranthus mangostanus to nitrogen and phosphorus addition. Sci Rep 6:37219. https://doi.org/10.1038/srep37219

35. Persson J, Fink P, Goto A, Hood JM, Jonas J, Kato S (2010) To be or not to be what you eat: regulation of stoichiometric homeostasis among autotrophs and heterotrophs. Oikos119(5):741751. https://doi.org/10.1111/j.1600-0706.2010.18545.x

36. Reich PB, Oleksyn J (2004) Global patterns of plant leaf $N$ and $P$ in relation to temperature and latitude. PNAS 101(30):11001-11006. https://doi.org/10.1073/pnas.0403588101

37. Sardans J, Rivas-Ubach A, Peñuelas J (2012) The elements stoichiometry of aquatic and terrestrial ecosystems and its relationships with organismic lifestyle and ecosystem structure and function: a review and perspectives. Biogeochemistry 111(1-3):1-39. https://doi.org/ 10.1007/s10533-011-96409

38. Sardans J, Peñuelas J (2015) Potassium: a neglected nutrient in global change. Glob Ecol Biogeogr 24:261-275. https://doi.org/10.1111/geb.12259

39. Shin R (2014) Strategies for improving potassium use efficiency in plants. Molecules Cells 37(8):575584. https://doi.org/10.14348/molcells.2014.0141 
40. Song ZL, Liu HY, Zhao FJ, Xu CY (2014) Ecological stoichiometry of N:P:Si in China's grasslands. Plant Soil 380(1-2):165-179. https://doi.org/ 10.1007/s11104-014-2084-y

41. Sterner RW, Elser JJ. (2002) Ecological stoichiometry: the biology of elements from molecules to the biosphere. Princeton University Press, Princeton.

42. Sun LK, Zhang BG, Wang B, Zhang GS, Zhang W, Zhang BL, Chang SJ, Chen T, Liu GX (2017) Leaf elemental stoichiometry of Tamarix Lour. species in relation to geographic, climatic, soil, and genetic components in China. Ecol Eng 106:448-457. https://doi.org/10.1016/j.ecoleng.2017.06.018

43. Sun G, Luo P, Wu N, Qiu PF, Gao YH, Chen H, Shi FS (2009) Stellera chamaejasme L. increases soil N availability, turnover rates and microbial biomass in an alpine meadow ecosystem on the eastern Tibetan Plateau of China. Soil Biol Biochem 41(1):86-

91. https://doi.org/10.1016/j.soilbio.2008.09.022

44. Tessier JT, Raynal DJ (2003) Use of nitrogen to phosphorus ratios in plant tissue as an indicator of nutrient limitation and nitrogen saturation. J Appl Ecol 40(3):523-34. https://doi.org/10.1046/j.13652664.2003.00820.x

45. Wang JN, Wang JY, Wang L, Zhang H, Guo ZW, Wang GG, Smith WK, Wu TG (2019) Does stoichiometric homeostasis differ among tree organs and with tree age. For Ecol Manag 453:117637. https://doi.org/10.1016/j.foreco.2019.117637

46. Wang XG, Lü XT, Dijkstra FA, Zhang HY, Wang XB, Wu YN, Wang ZW, Feng J, Han XG (2019) Changes of plant N:P stoichiometry across a $3000-\mathrm{km}$ aridity transect in grasslands of northern China. Plant Soil 443:107-119. https://doi.org/10.1007/s11104-019-04211-w

47. Wei YQ, Lu HY, Wang JN, Sun J, Wang XF (2019) Responses of vegetation zones, in the QinghaiTibetan Plateau, to climate change and anthropogenic influences over the last 35 years.

Pratacultural Science, 36(4):250-263 (in Chinese)

48. Wu JB, Wang XD (2019) Stoichiometric homeostasis does not affect species dominance and stability in an alpine steppe, Tibetan Plateau. Arct Antarct and Alp Res 51(1):18. https://doi.org/10.1080/15230430.2018.1560112

49. Yan ZB, Guan HY, Han WX, Han TS, Guo YL, Fang, JY (2016) Reproductive organ and young tissues show constrained elemental composition in Arabidopsis thaliana. Anna Bot 117(3):431. https://doi.org/10.1093/aob/mcv190

50. Yang XJ, Huang ZY, Zhang KL, Cornelissen JHC (2015) C:N:P stoichiometry of Artemisia species and close relatives across northern China: unravelling effects of climate, soil and taxonomy. J Ecol 103(4):1020-1031. https://doi.org/10.1111/1365-2745.12409

51. Yu Q, Chen QS, Elser JJ, He NP, Wu HH, Zhang GM, Wu JG, Bai YF, Han XG (2010) Linking stoichiometric homoeostasis with ecosystem structure, functioning and stability. Ecol Lett 13:13901399. https://doi.org/10.1111/j.1461-0248.2010.01532.x

52. Yu Q, Elser JJ, He NP, Wu HH, Chen QS, Zhang GM, Han XG (2011) Stoichiometric homeostasis of vascular plants in the Inner Mongolia grassland. Oecologia 166:1-

10. https://doi.org/10.1007/s00442-010-1902-z

Page $17 / 23$ 
53. Yu Q, Wilcox K, La Pierre K, Knapp AK, Han XG, Smith MD (2015) Stoichiometric homeostasis predicts plant species dominance, temporal stability, and responses to global change. Ecology 96:2328-2335. https://doi.org/10.1890/14-1897.1

54. Zhang CH, Zhang L, Wu YJ, Liu PT, Li YL (2019) Assessment on the integrated drought disaster risk in Inner Mongolia grassland. Journal of Arid Land Resources and Environment, 33(7): 115-121 (in Chinese).

55. Zhang HY, Wu HH, Yu Q, Wang ZW, Wei CZ, Long M, Kattge J, Smith M, Han XG (2013) Sampling Date, Leaf age and root size: implications for the study of plant C:N:P stoichiometry. PLoS ONE, 8(4): e60360. https://doi.org/10.1371/journal.pone.0060360

56. Zhang Q, Liu Q, Yin HJ, Zhao CZ, Zhang L, Zhou GY, Yin CY, Lu ZJ, Xiong GM, Li YL (2019) C:N:P stoichiometry of Ericaceae species in shrubland biomes across Southern China: Influences of climate, soil and species identity. J Plant Ecol (2):346-357. https://doi.org/ 10.1093/jpe/rty033

57. Zhang YH, Zhang JW, Li ZM, Sun H (2015) Genetic diversity of the weed species, Stellera chamaejasme, in China inferred from amplified fragment length polymorphism analysis. Weed Biol Manag 15(4):165-174. https://doi.org/10.1111/wbm.12084

\section{Figures}



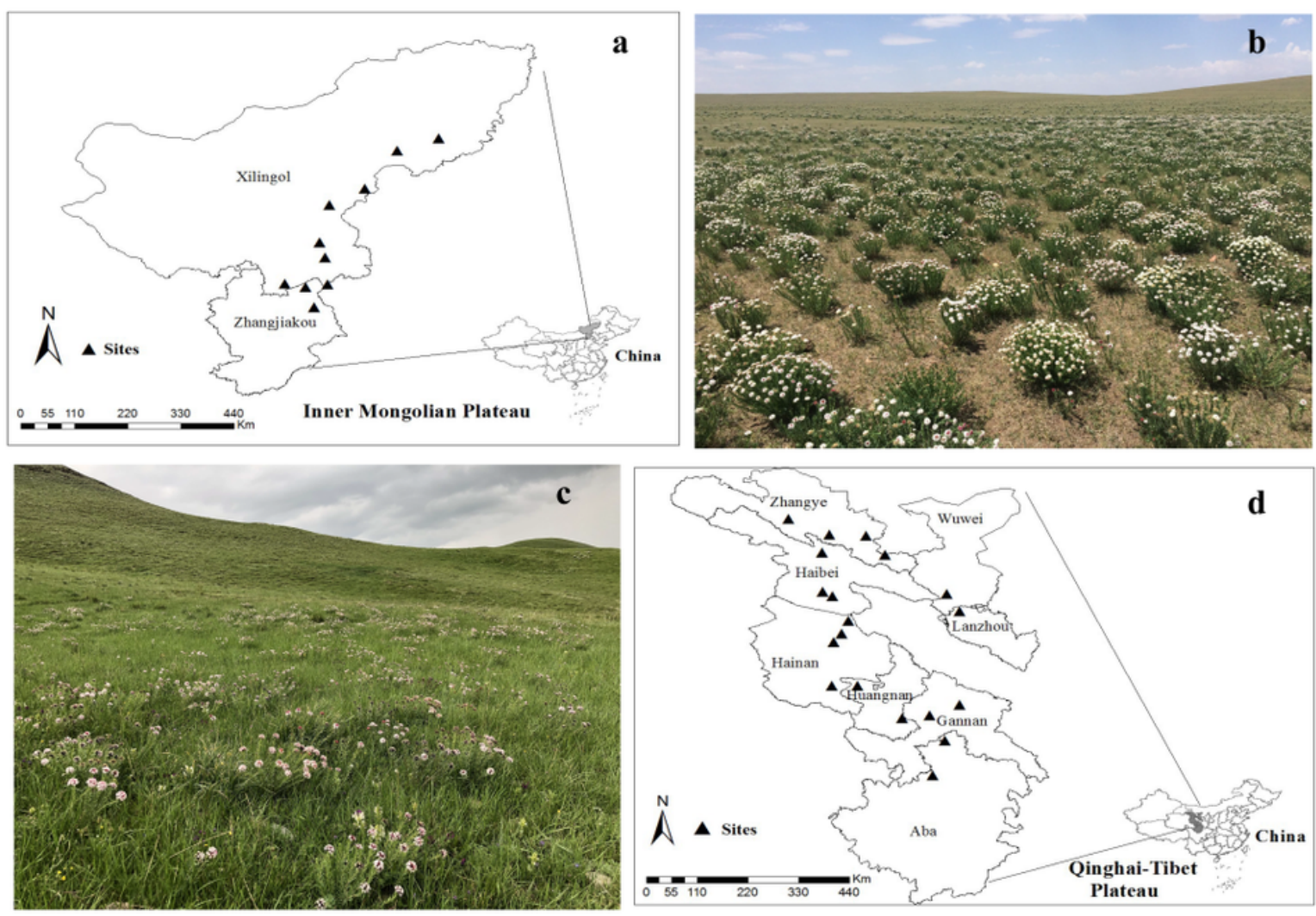

\section{Figure 1}

Location of the study and sampling sites. (a) Sampling sites on Inner Mongolia Plateau; (b) S. chamaejasme coverage in Taipusi Banner on Inner Mongolia Plateau; (c) Sampling sites on QinghaiTibetan Plateau; and (d) S. chamaejasme coverage in Qilian County on Qinghai-Tibetan Plateau. 


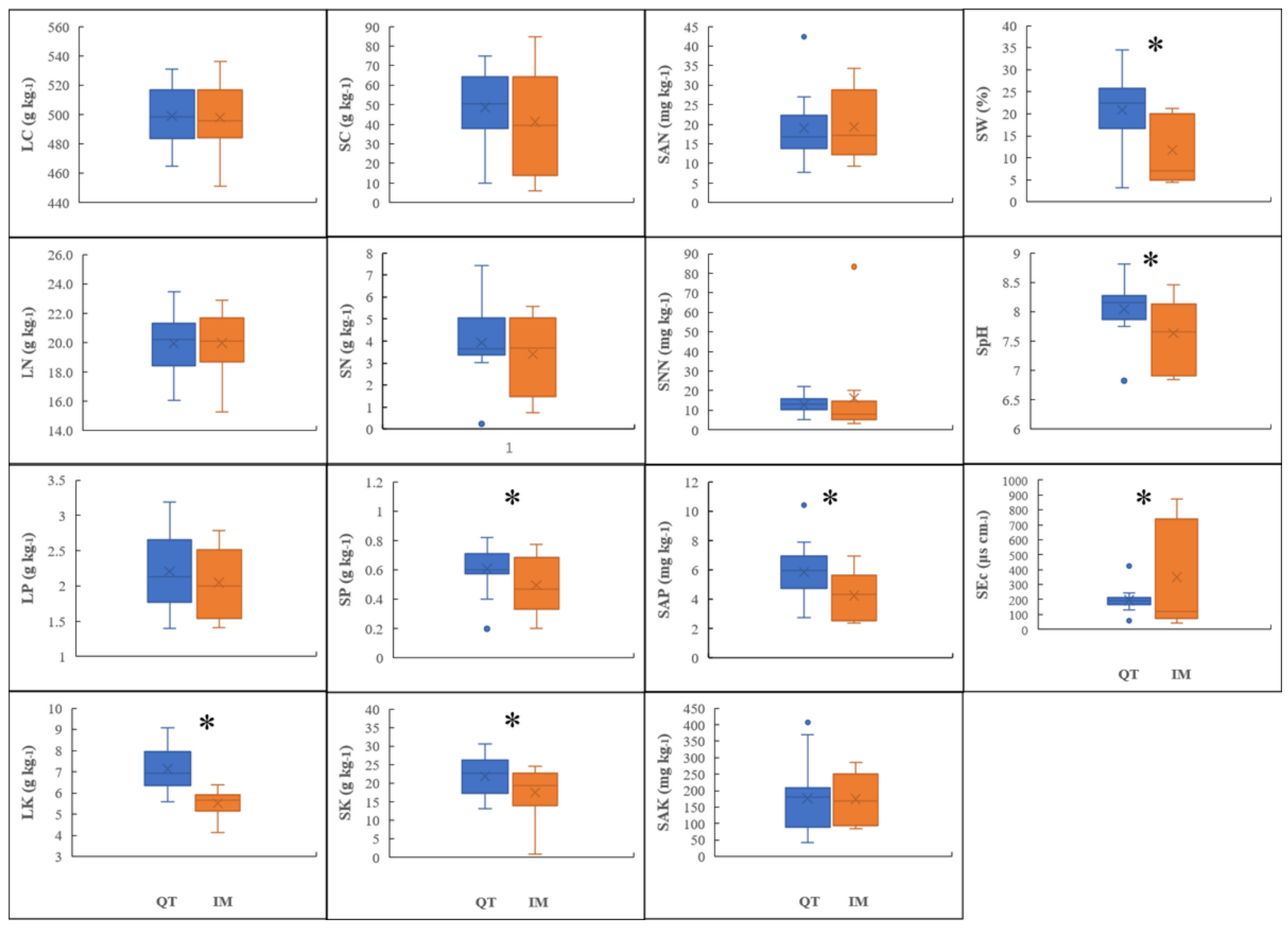

Figure 2

Comparison of leaf element contents and soil physiochemical properties in Qinghai Tibetan Plateau (QT, $\mathrm{n}=19)$ and Inner Mongolian Plateau (IM, $\mathrm{n}=10)$ Note: Significant differences $(\mathrm{P}<0.05$ on the basis of $\mathrm{t}-$ test) between the QT and IM were indicated by *. 

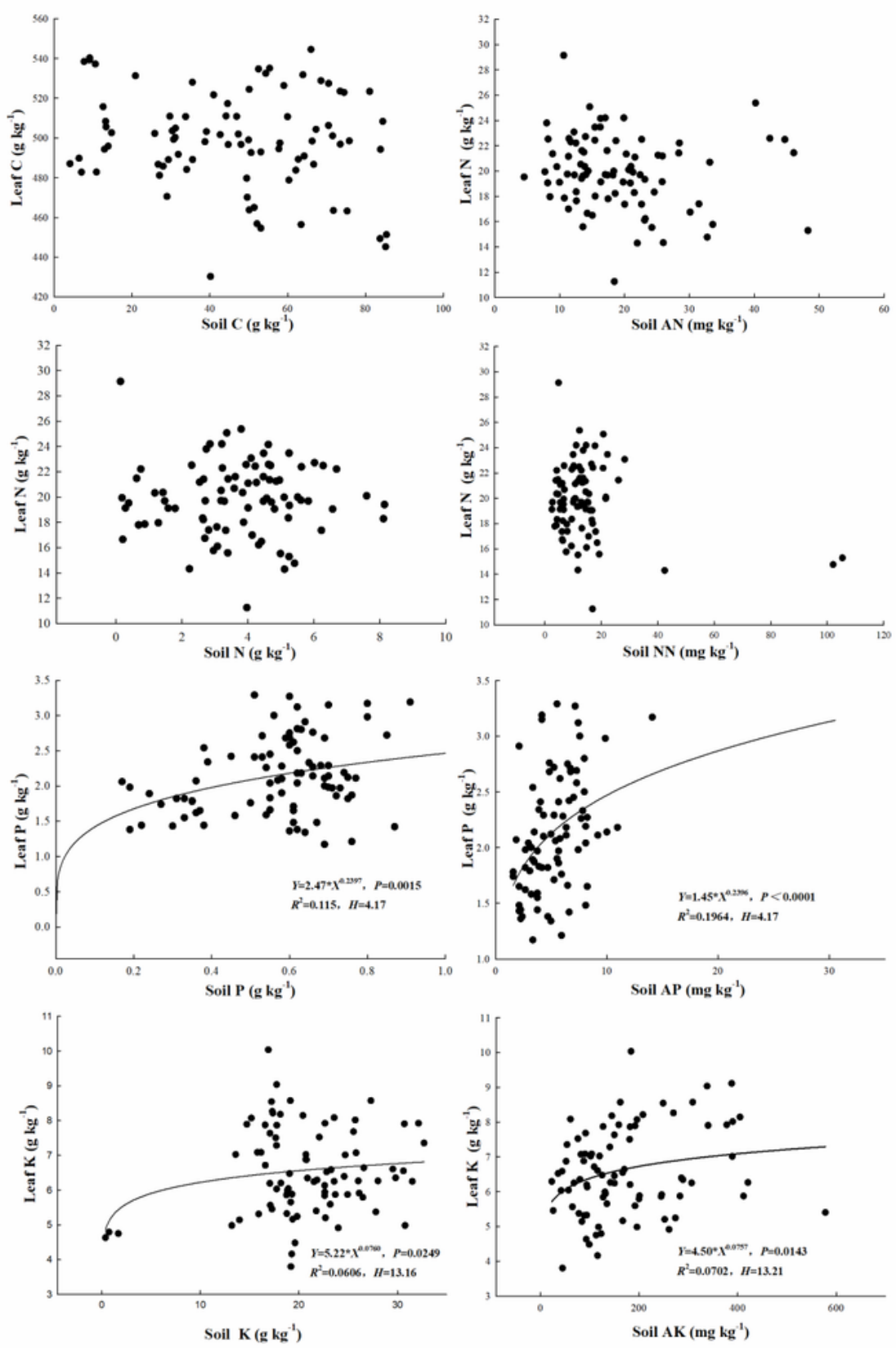

Figure 3

Relationship between the content of $\mathrm{C}, \mathrm{N}, \mathrm{P}, \mathrm{K}$ elements in $\mathrm{S}$. chamaejasme leaves and soil 


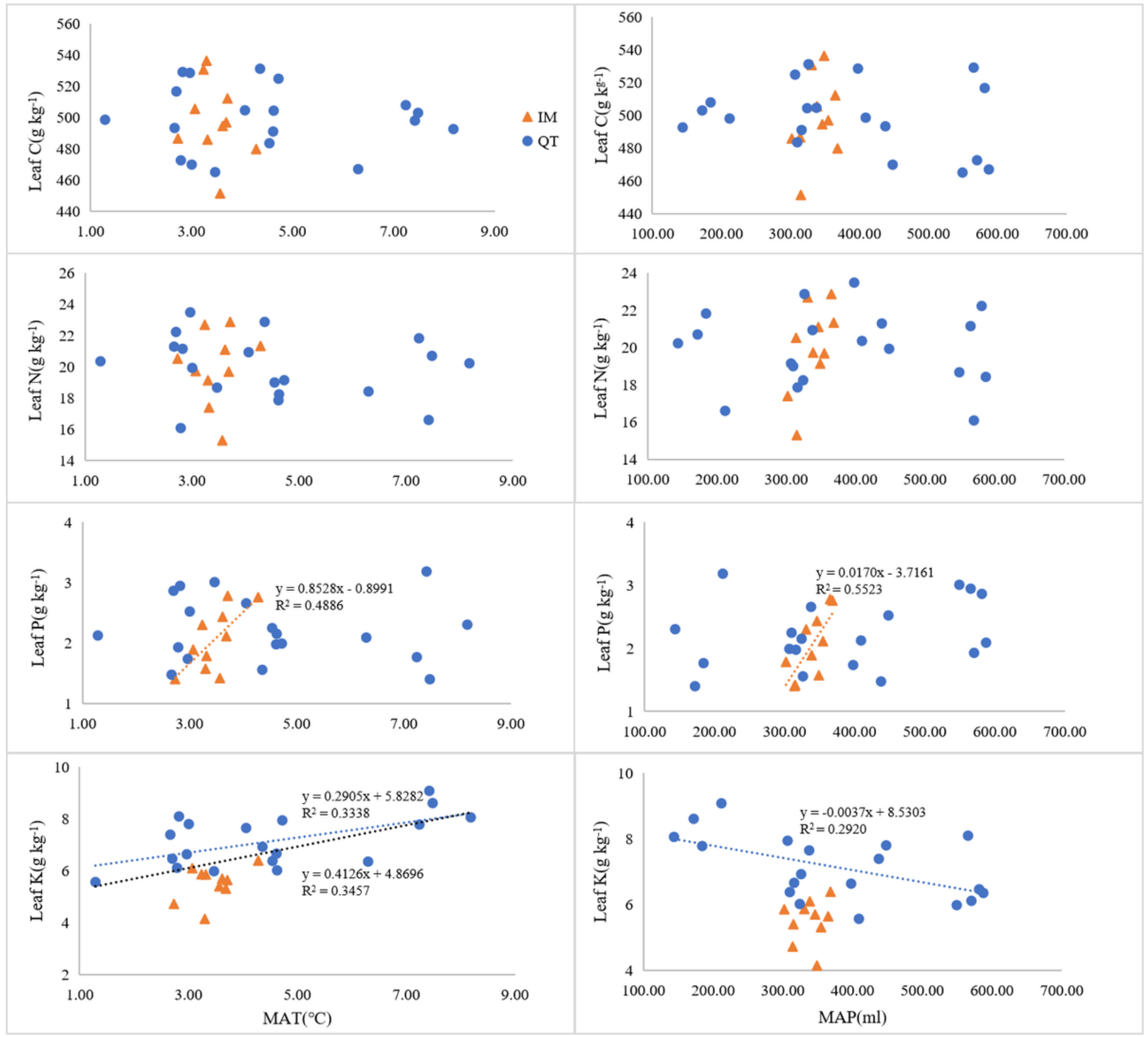

Figure 4

Leaf C, N, P, K content of S. chamaejasme in relation to climate factors (MAT \& MAP) in Qinghai Tibet Plateau (blue circles) and Inner Mongolia Plateau (red triangles). 

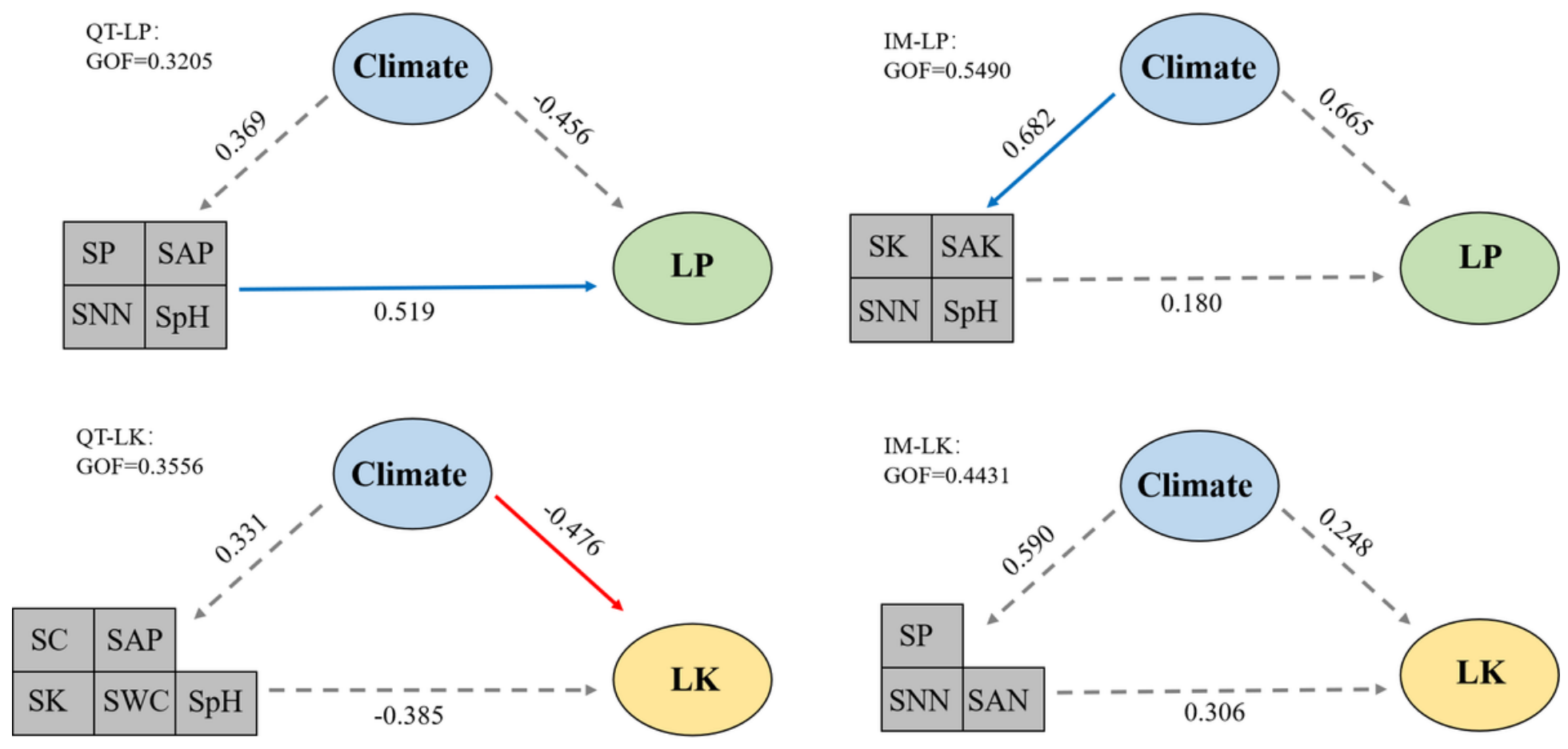

\section{Figure 5}

Effects of different variables (soil and climatic variables) on the leaf $\mathrm{P}$ and $\mathrm{K}$ of $\mathrm{S}$. chamaejasme in Qinghai Tibet Plateau (QT) and Inner Mongolia Plateau (IM) based on partial least squares path modeling. The blue arrows represent positive pathways, and the red arrows indicate negative pathways. The standard path coefficients are showed on the arrow. GOF, goodness of fit of the statistical model.

\section{Supplementary Files}

This is a list of supplementary files associated with this preprint. Click to download.

- SupplementarymaterialGLZ.doc 